UNIVERSIDADE DE BRASÍLIA UNIVERSIDADE ABERTA DO BRASIL INSTITUTO DE ARTES VISUAIS

NÁDIA REIGOTA SOARES

O USO DE MÁSCARA COMO INSTRUMENTO PEDAGÓGICO 
NÁDIA REIGOTA SOARES

\section{O USO DE MÁSCARA COMO INSTRUMENTO PEDAGÓGICO}

Trabalho de conclusão de curso de Artes Visuais, habilitação em Licenciatura, do Departamento de Artes Visuais do Instituto de Artes da Universidade de Brasília.

Orientadora: Profa ${ }^{\mathrm{a}}$. Me. Cecília Mori Cruz

Tutor à distância: Me. André de Carvalho Barreto

Itapetininga

2011 


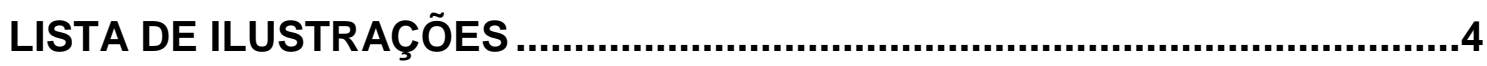

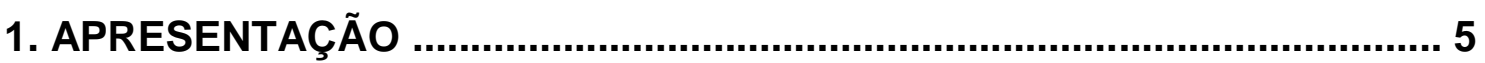

2. USANDO MÁSCARA E DESMASCARANDO O SUJEITO ............................

3. O USO DE MÁSCARA PELA HUMANIDADE ..........................................13

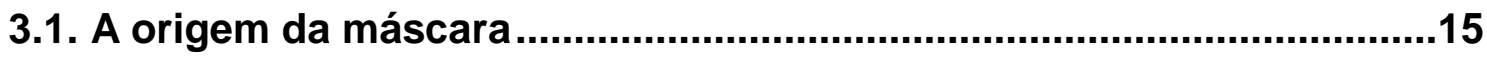

3.2. A máscara na Antiguidade - Egito, Grécia e Roma ................................16

3.3. A máscara como elemento ritualístico...................................................22

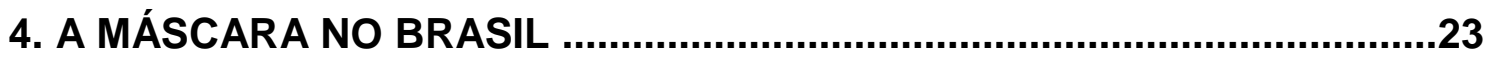

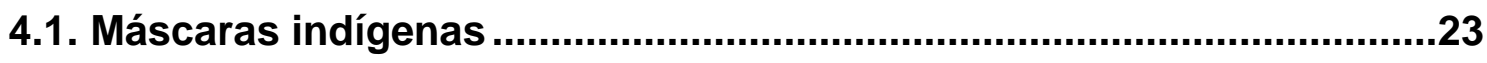

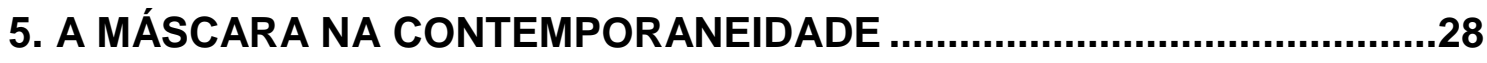

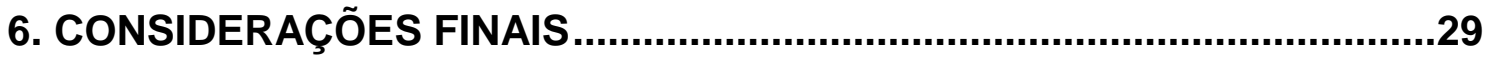

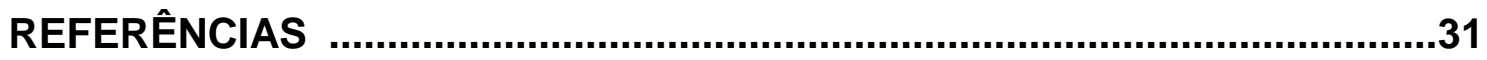




\section{LISTA DE ILUSTRAÇÕES}

Figura 1: Máscaras de papelão feitas por alunos da EE Prof. Sebastião

Villaça, Itapetininga

Figura 2: Molde com atadura gessada sendo retirado do rosto do modelo.

Figura 3: Molde com atadura gessada sendo retirado do rosto do modelo.

Figura 4: Elaboração estética das máscaras usando sementes.

Figura 5: Elaboração estética das máscaras usando retalhos de tecido.

13

Figura 6: Elaboração estética das máscaras usando materiais alternativos como papel reciclado, sementes, tecido e folhas secas.

Figura 7: Máscara veneziana.

Figura 8: Jovem da tribo Omo, da Etiópia. 16

$\begin{array}{ll}\text { Figura 9: Máscara de Agamenon } & 17\end{array}$

Figura 10: Máscara mortuária egípcia em madeira 18

Figura 11: Máscara mortuária de Tutancâmon 19

Figura 12: Máscara teatral do tipo Primeiro Escravo 20

Figura 13: Máscara romana de Kalkriese. 20

Figura 14: Máscara de Dionísio, Myrina 22

Figura 15: Aldeia Macaúba, Aruanã, llha da Banana 25

Figura 16: Tribo Waujá, Aldeia Piyulaga 26

Figura 17: Máscaras do sobrenatural Tomokó dos índios Wayana-Apalay 27

Figura 18: Máscaras do sobrenatural Kokrit dos índios Kanela e Kahó $\quad 27$

Figura 19: Festa dos Kokrit, índios Kanela 28 


\section{APRESENTAÇÃO}

Partindo do tema questão "o conhecimento do uso de máscaras na antiguidade e a sensibilização dos alunos para o tema", tive a preocupação de que alunos em diversas idades pouco ou nada sabem, nem ao menos procuram saber sobre a Arte na Antiguidade. Este período da história da arte que apresenta tantas descobertas e desenvolvimento cultural, social, científico, artístico, não é tão explorado nem tão conhecido pela maioria de alunos do ensino médio.

Assim desenvolvi uma pesquisa que procurasse apresentar e desenvolver nos alunos a curiosidade de conhecimento de como ocorreu o desenvolvimento humano, podendo assim compreender melhor o mundo no qual estamos inseridos.

Após alguns anos em sala de aula, o professor passa a compreender melhor as atitudes dos alunos e procura direcionar o seu conhecimento e experiência com a finalidade de suprir as necessidades de aprendizagem e compreensão dos mesmos. Visto que a participação e interesse do aluno de artes visuais estão ligados ao fazer artístico, é necessário saber dosar teoria e prática para que juntas complementem a aprendizagem do aluno. Ambas são indispensáveis ao bom desenvolvimento de aprendizagem de qualquer pessoa. Sem uma, a outra acaba ficando com lacunas, mas quando são trabalhadas de forma coerente e juntas, completam todo o processo de aprendizagem.

Devido à convivência com o corpo discente, foi possível perceber que muitos não possuem uma boa motivação para realizar um trabalho, fazendo assim com que não se interessem por tema algum, aliás, não somente o aluno, mas a maioria dos seres humanos, sejam em qualquer faixa etária em que se encontram até mesmo em situações corriqueiras da vida, necessitam de motivação para realizar alguma ação.

Segundo Ana Lucia Santana (colunista do site Info Escola), a Máscara é um elemento, que faz aflorar no ser humano, um sentimento ou vontade de assumir outro papel, de apropriar-se de outra personalidade como uma fuga ou tentativa de melhorar ou sanar algum problema, ou até mesmo realizar algum desejo. Ela faz 
parte da História da Humanidade durante o desenvolvimento da cultura de diferentes povos desde o homem pré-histórico, encontramos sua presença adaptando-se aos mais variados significados. Sendo assim, este tema foi escolhido como foco principal do projeto, acreditando que esta proposta poderia contemplar os envolvidos no desenvolvimento do projeto.

Durante todo o curso de Artes Visuais, foram pesquisadas e estudadas as mais variadas formas de expressão artística. Dentre as propostas de atividades, esteve presente a história da arte e do teatro, no qual constava a presença das Máscaras usadas na Commédia Dell'Arte. Pôde-se então a perceber, que ao tratarse da história e cultura da humanidade, a Máscara está sempre presente, seja em rituais religiosos ou mesmo para assumir o papel de algum personagem histórico ou super-herói, mesmo na contemporaneidade, a máscara aparece por vezes de forma imaterial, com outros significados, encobrindo situações que envolvem, muitas vezes, questões delicadas de origens diversas como, por exemplo, a corrupção, o desvio de verbas ou materiais, camuflando personalidade, caráter e responsabilidade por ações que não são realizadas.

O estudo deste tema tem a proposta de mostrar ao aluno que existem várias formas de expressão artística para que ele possa mostrar suas ideias, emoções e pensamentos que até então, ele não sabia ou tinha receio de como poder se expressar. Através do trabalho com a Máscara, o aluno poderá desenvolver algumas atividades como pesquisa, percepção da forma e da cor, o uso de materiais e suas mais diversas texturas, criatividade, coleta e seleção de materiais e descobrir uma nova maneira de se expressar. Fazendo ao mesmo tempo, uma conexão entre os conteúdos das artes visuais com as artes cênicas. Levando para a sala de aula, uma proposta de estudo da história da arte junto com práticas de trabalhos visuais, que seriam a elaboração prática de máscaras criadas pelos alunos.

Em suma, o trabalho que se propõe com máscaras é bastante amplo no que diz respeito à criação estética visual, se unido a outras disciplinas seu campo como elemento didático aumenta ainda mais, pois todas as outras linguagens do saber podem lançar mão de um recurso como este, pode ainda ser peça chave de um projeto que envolva não somente os alunos de uma escola, mas toda a comunidade em que esta se encontra. 
Em seguida, ao final do projeto, haverá uma atividade de elaboração da parte estética das máscaras com materiais alternativos, este pode ser usado como forma de conscientização de cuidados com o meio ambiente, fato muito questionado nos dias atuais.

É importante salientar que dentro do método de trabalho, o aluno conheça a história de diversos povos antes de iniciar seu trabalho, pois assim será capaz de escolher a melhor maneira de expressar suas idéias e como o fazer. O aluno perceberá que existem inúmeras formas de realizar uma máscara e outras tantas de personalizá-la, orientando-se pelas características próprias de cada época e cada cultura, que irão nortear o caminho que o aluno/criador irá percorrer e desenvolver.

Ao findar de todo o processo de criação das máscaras, o aluno será capaz de perceber que objetos simples, antes destinados a um único objetivo, até mesmo elementos do seu cotidiano, poderão ser usados como elementos artísticos se forem apropriados e destinados a outros segmentos da criação artística quando lhe dado o devido sentido e significado.

O aluno verá que pode expor suas idéias de diferentes formas, e que é capaz de transformar o meio que vive, modificando conceitos e criando novas formas de contato, preservando ainda a cultura da sociedade em que se encontra inserido. Ou ainda, quem sabe criando novas formas de expressão artística, marcando um novo tempo na história da arte, já que nos deparamos com tantas novidades a cada segundo. 


\section{USANDO MÁSCARA E DESMASCARANDO O SUJEITO}

Para despertar nos alunos a curiosidade de conhecer e compreender o mundo antigo faz-se necessário a elaboração de um projeto que torne atraente, visto que o uso da tecnologia, hoje em dia, é muito mais atraente, rápida e eficaz que muitas outras formas de aprendizagem.

Este projeto tem por objetivo incentivar o aluno a se interessar pelo período antigo, de maneira que os alunos possam conhecer o desenvolvimento de um povo, bem como sua cultura e modo de vida, compreendendo o desenvolvimento que ocorre na atualidade e que possa vir a aceitar o desenvolvimento futuro, usando elementos visuais como cor, forma, textura, na confecção das suas máscaras.

A primeira etapa de um projeto que poderia ter como tema "A expressão através das Máscaras," é apresentar uma proposta de trabalho aos alunos com pesquisa de elaboração de texto e coleta de imagens que servirão de base para a confecção de máscaras elaboradas por eles em três técnicas diferentes. Primeiramente, deve-se agendar e preparar a sala de computação, bem como analisar alguns sites previamente para serem sugeridos aos alunos. Levando os alunos a uma sala de computação para a pesquisa, seria melhor se orientá-los para que façam anotações (usando as folhas sulfites e lápis grafiti, que estariam à disposição nos computadores), daquilo que Ihes chamaria a atenção, podendo ainda salvar imagens e textos (que poderão ser salvos em pendrive ou serem impressos), para posteriores consultas durante todo o processo de produção e desenvolvimento das atividades do projeto.

Uma segunda visita, com foco em pesquisa seria proposta na biblioteca da escola, que também deveria ser pesquisada antes pelo professor e fazendo uma 
seleção, previamente, de possível bibliografia para consulta dos alunos, onde também poderão fazer as anotações que mais acharem pertinentes.

Com todo o material coletado, partiríamos para a etapa de criação em esboços de possíveis peças a serem confeccionadas pelos alunos. A proposta é que criem, no mínimo, três desenhos de máscaras as quais poderiam ser confeccionadas, cartografando os detalhes, como cor, forma e detalhes da peça. Em seguida, lembrando das imagens encontradas e coletadas durante a pesquisa, criarse-ia uma lista de possíveis materiais para serem usados na elaboração estética das máscaras como, por exemplo, materiais alternativos e que seriam indevidamente descartados, como papel de coador de café, retalhos de tecido, tipos variados de sementes, parafusos e arruelas, tampinha plásticas, embalagens coloridas de xampu, dentre outros. Escolhido os materiais possíveis de serem utilizados, os alunos coletariam esse material e o acondicionariam para ser usado na etapa da elaboração estética das máscaras.

Como primeira experiência do fazer artístico de uma máscara, usaríamos como suporte o papelão. Este poderá ser cortado no formato de círculo ou oval, com dois piques na parte superior da testa onde serão sobrepostas as pontas e grampeadas para dar volume ao material plano. Nesse suporte, o aluno desenharia os detalhes da máscara, baseando-se nas máscaras encontradas durante a pesquisa, escolhendo a época que irá representar, apenas pintando seu trabalho para depois fazer uma segunda máscara, que será decorada com materiais alternativos e reciclados, podendo ser colados com cola quente ou cola branca.

Alunos da EE Prof. Sebastião Villaça, em Itapetininga, realizaram atividades de elaboração de máscaras africanas em um projeto desenvolvido na escola, tendo como tema "Afro Brasil". Os alunos orientados pela professora de Arte fizeram uma pesquisa, sobre tribos africanas que utilizaram e ainda utilizam a máscara em diferentes rituais, destacando características artísticas visuais destas peças, como forma, cor, linha, textura e materiais utilizados para a fabricação e elaboração estética das mesmas.

Os alunos constataram que os africanos, assim como os indígenas brasileiros, utilizam o material disponível e encontrado em seu território, para elaborar a ornamentação estética das máscaras, como madeira, palha e casca de árvores. A partir desta percepção de uso de materiais, os alunos perceberam que 
podem elaborar a estética de suas máscaras usando os materiais que encontrarem mais próximos a eles, na comunidade ou até mesmo dentro de casa, como alguns materiais descartados indevidamente como plásticos, papéis, peças de alumínio.

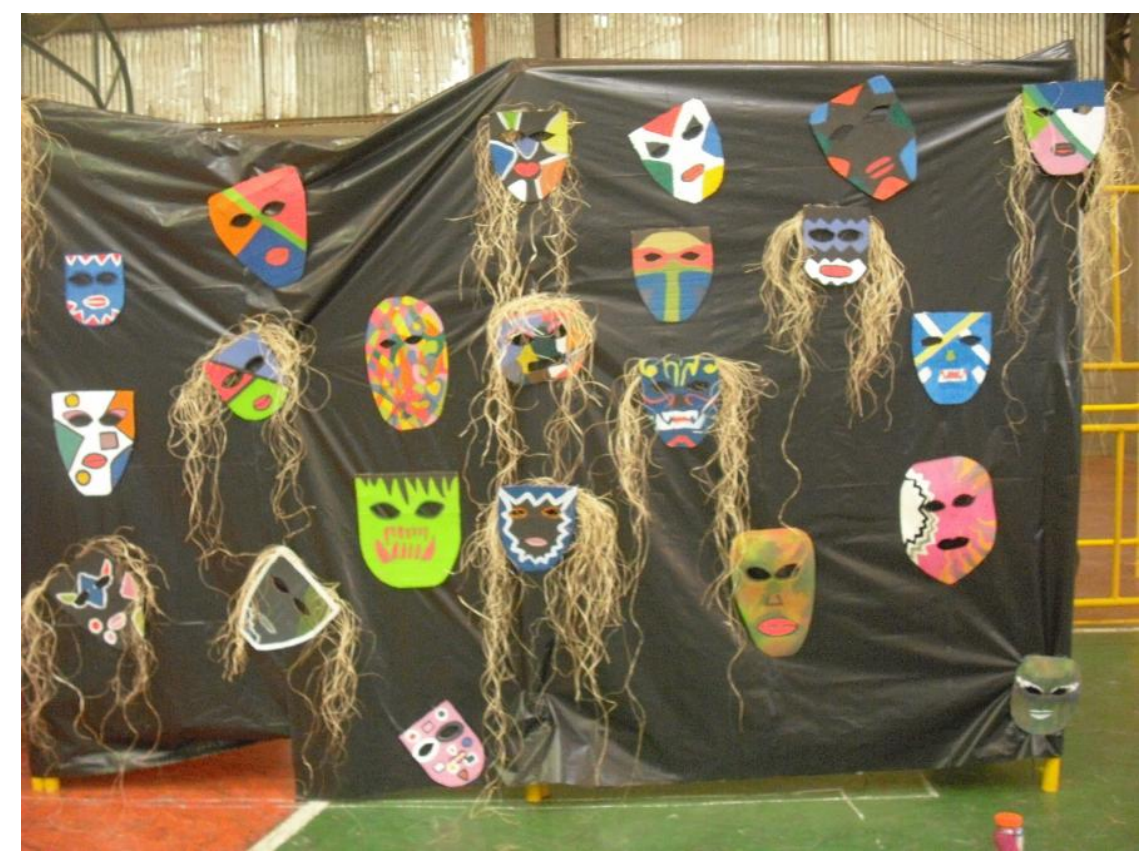

Figura1: máscaras africanas de papelão feitas por alunos da EE Prof. Sebastião Villaça, Itapetininga (arquivo particular)

A segunda etapa de confecção das máscaras, como uma segunda técnica oferecida aos alunos, seria tirar o molde do rosto de um colega. Para esta etapa usaríamos plástico fino que poderá ser sacolinhas de supermercado ou outro material parecido e fita crepe. O plástico será moldado no rosto do colega procurando deixar narinas e boca a mostra, no caso de máscara inteira. Em seguida, com pedaços de fita crepe, vai-se moldando o formato do rosto, são necessárias cerca de três camadas de fita crepe. Em seguida vamos empapelar toda a máscara.

Com várias fitas de papel jornal recortado e embebido em um mistura de água com bastante cola, molharíamos e colocaríamos o papel sobre o molde que já foi retirado do rosto do colega. Após cerca de cinco camadas, deixamos secar de um dia para outro se o tempo estiver calor, ou dois dias se estiver frio ou chuvoso. Após este tempo, ela deverá estar seca e dura, caso contrário, deixar por mais tempo. 
Quando estiver totalmente seca, usando tesoura, devemos aparar a beira e narinas da máscara para um melhor acabamento. Somente então partiremos para a elaboração estética, onde uma das máscaras será devidamente pintada e a outra ornamentada com materiais alternativos.

Após retirar o molde do rosto de um colega, usaríamos como suporte, a atadura gessada, sendo que para cada máscara, usamos cerca de um rolo de atadura. $O$ rosto que será retirado o molde deverá ser devidamente preparado com creme hidratante, para em seguida, recortar tiras pequenas e de tamanhos variados da atadura para ser ajustada ao rosto, que será retirado o molde, procurando manter as características, como formato de sobrancelhas, narinas, queixo, formato do rosto. Após três camadas de atadura, o gesso estará secando e o molde se soltando do rosto. Em seguida, retira-se o molde e com a tesoura dar acabamento nas rebarbas da atadura que ficaram sobrando. Depois seria necessário colocar mais duas camadas de atadura reforçando as beiradas do molde e, quando estiver bem seco, passariam uma camada espessa de massa corrida usada em parede, tentando deixá-la o mais liso possível.

Depois que a massa corrida secar, por cerca de um ou dois dias, com uma lixa d'água ou outra lixa bem fina, com cuidado e movimentos leves, alisar a superfície da máscara que estaria pronta para ser pintada. A tinta a ser utilizada seria acrílica ou plástica que dão brilho e colorido mais forte. Se for cobrir toda a superfície da máscara com outro tipo de material, a lixa será desnecessária, pois a superfície irregular ajuda na colagem dos materiais a serem usados.

Após a realização dos trabalhos, as peças deverão ser expostas em um ambiente que propicie a valorização das mesmas, podendo-se pensar em algo que remeta o visitante à antiguidade ou da época que a que esta se refere.

Uma avaliação de todo o percurso do projeto também se faz necessária para que sejam levantados pontos de acertos e erros para devidas correções. Esta avaliação poderá acontecer durante todo o processo de criação em determinados momentos que a realização dos trabalhos pára, e será então, realizada uma análise e troca de idéias entre os componentes de toda a turma. 


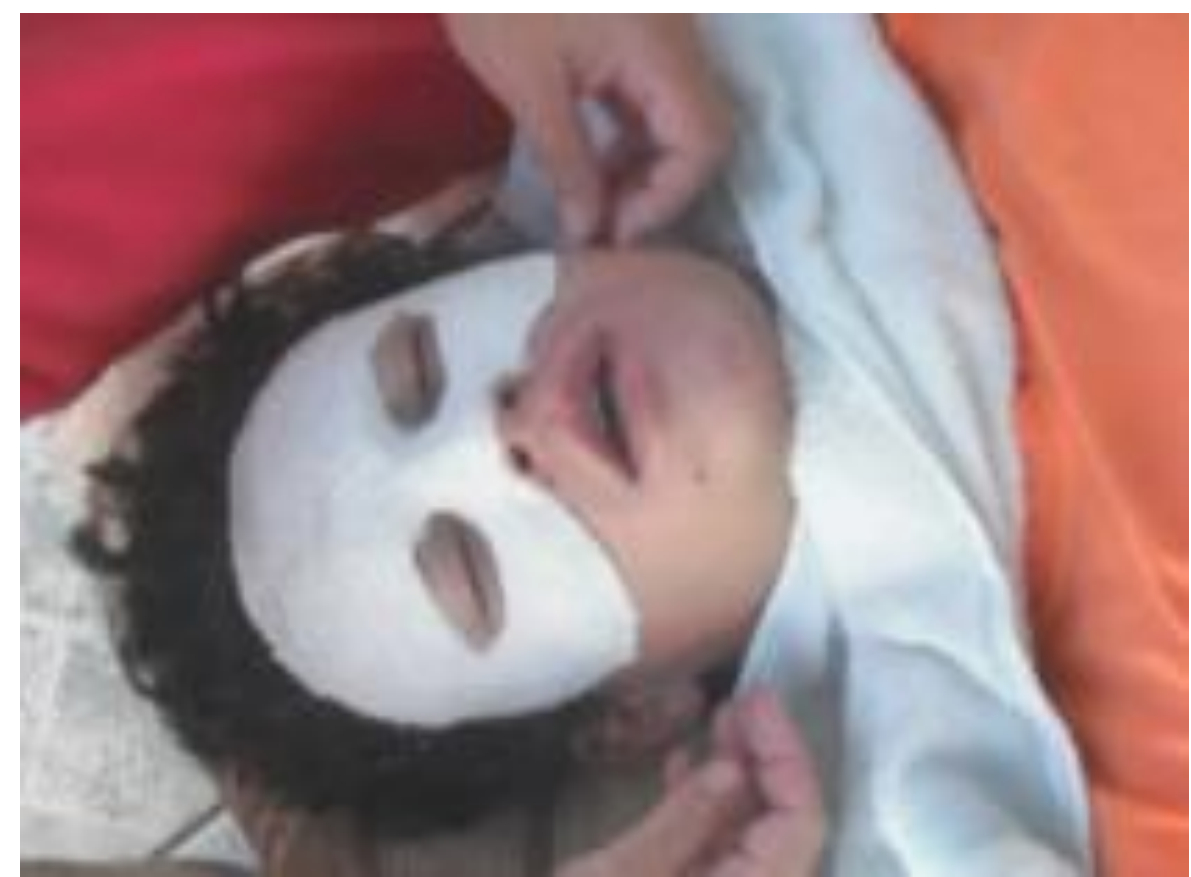

Figura 2: Molde com atadura gessada sendo retirado do rosto do modelo. Arquivo pessoal.

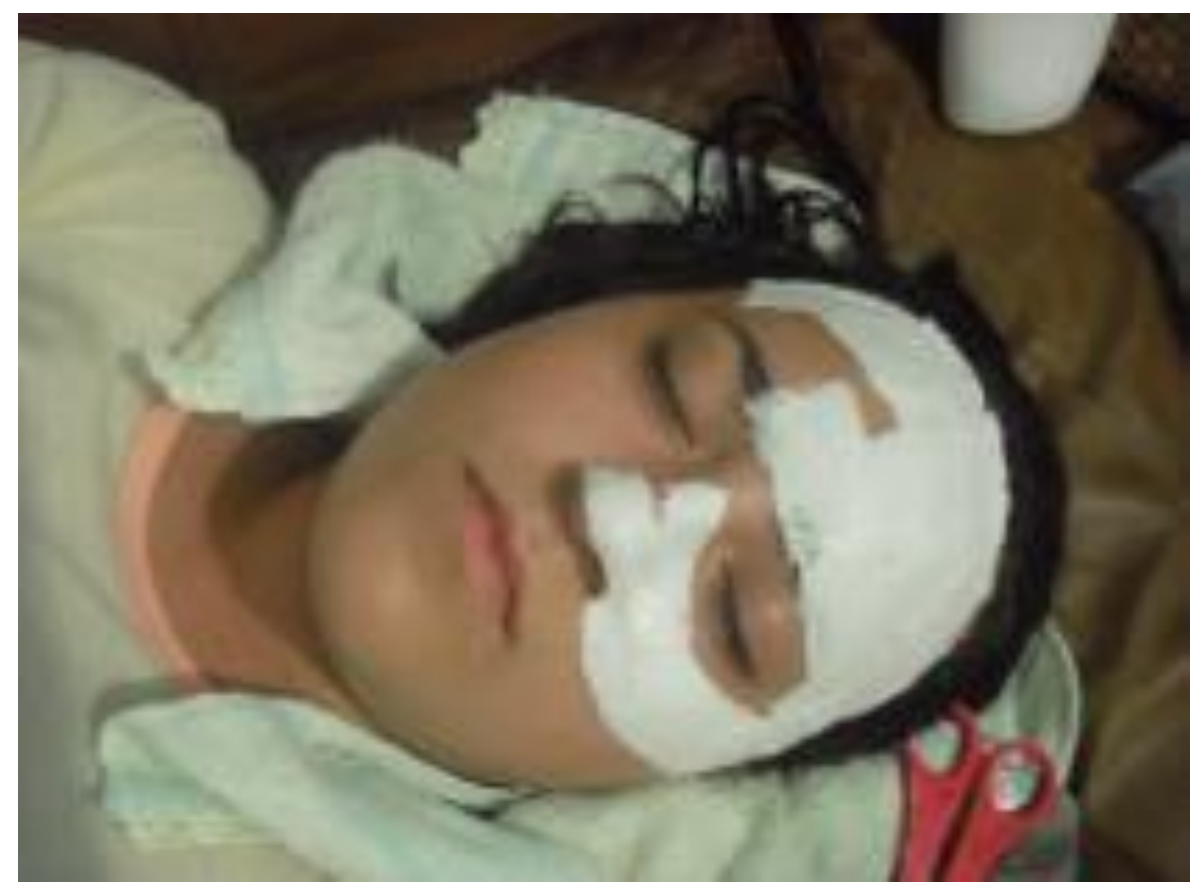

Figura 3: Molde com atadura gessada sendo retirado do rosto do modelo. Arquivo pessoal. 


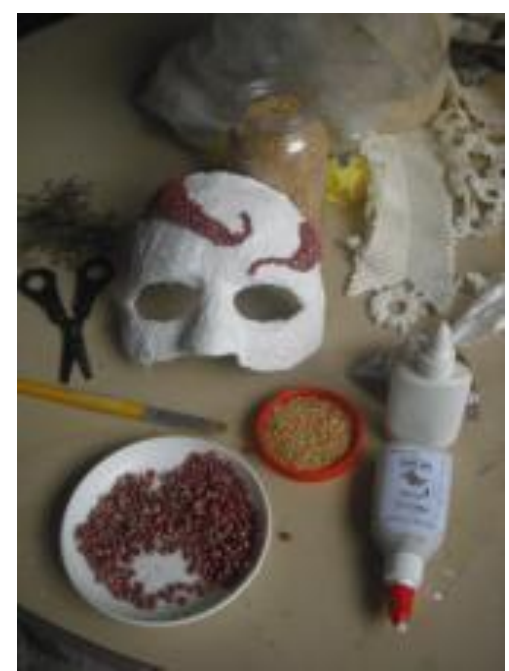

Figura 4: Elaboração estética das máscaras usando sementes. Arquivo pessoal.

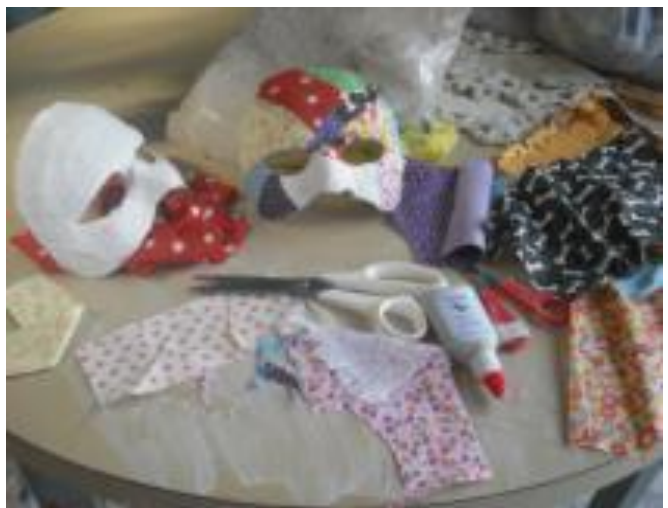

Figura 5: Elaboração estética das máscaras usando retalhos de tecido. Arquivo pessoal.

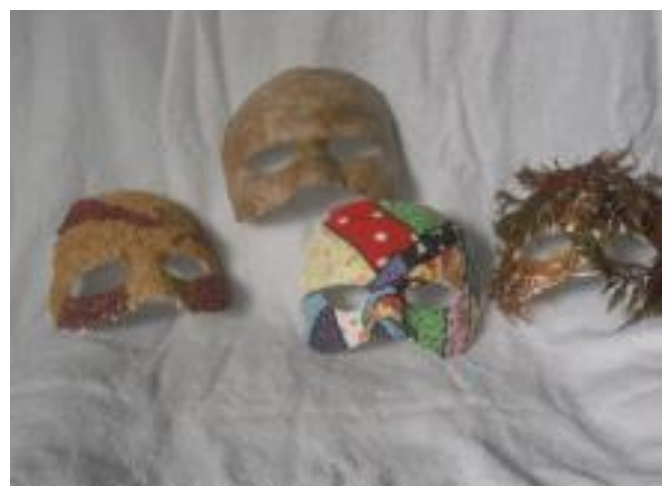

Figura 6: Elaboração estética das máscaras usando materiais alternativos como papel reciclado, sementes, tecido e folhas secas. Arquivo pessoal. 


\section{O USO DE MÁSCARA PELA HUMANIDADE}

Segundo Pedro Alcântara (educador brasileiro), ao tentarmos definir o que é uma máscara, nos deparamos com dois conceitos opostos: um define a máscara como sendo um elemento teatral, que tem por finalidade, se caracterizar e dar vida a um personagem. $O$ outro, esconder o rosto daquele que a esta usando, impedindo que seja reconhecido e, sendo assim, tem dupla função como incógnito e como segundo rosto. Ela é presença marcante em vários momentos na história da humanidade, desde os tempos mais distantes. Feitas com os mais diferentes materiais desde os mais nobres até mesmo os mais simples, tirados da natureza que não deixam de ter seu valor e significado.

Ana Lucia Santana (colunista do site Info Escola) diz que várias culturas de diversos cantos do mundo criaram suas máscaras para suprir suas necessidades e materializar suas divindades, dando assim, vida aos seres inanimados e aqueles que acreditam poder assumir sua forma e poder, tornando a máscara um elemento de grande importância na cultura de um povo, sendo indispensável e insubstituível dentro de uma comunidade e assumindo os mais variados objetivos, desde um ritual religioso até a composição de um personagem ou mesmo para esconder ou disfarçar um rosto. Como permite ao usuário à incorporação de um novo universo e personalidade a nobreza da cidade de Veneza, no século XI, usava-se a máscara para tentar se disfarçar e se misturar ao povo durante os dias de carnaval que duravam até seis meses. Sendo assim, todos estariam livres para se relacionarem com quem desejassem, pois teriam sua identidade preservada. Aos poucos as máscaras passaram a fazer parte da vida dos venezianos, eram usadas em jantares, encontros e mesmo na rua sem que tivessem algum motivo especial.

Após diversas pesquisas, compreende-se que a máscara é tão antiga quanto a história da humanidade, ela vem tentando se adaptar as novas idéias e necessidades das pessoas, sendo usadas para os mais variados fins desde um ritual religioso até como complemento da criação de um personagem ou mesmo para esconder ou adquirir uma nova personalidade. A máscara faz com que 0 
homem seja criativo e desenvolva modelos e descubra materiais novos e acessíveis como são os reciclados. Enfim, existe uma variedade muito grande de tipos de máscaras e como a tecnologia, a cada momento, surge um novo modelo de máscara, para ser usada nos mais variados momentos da história como veremos a seguir.

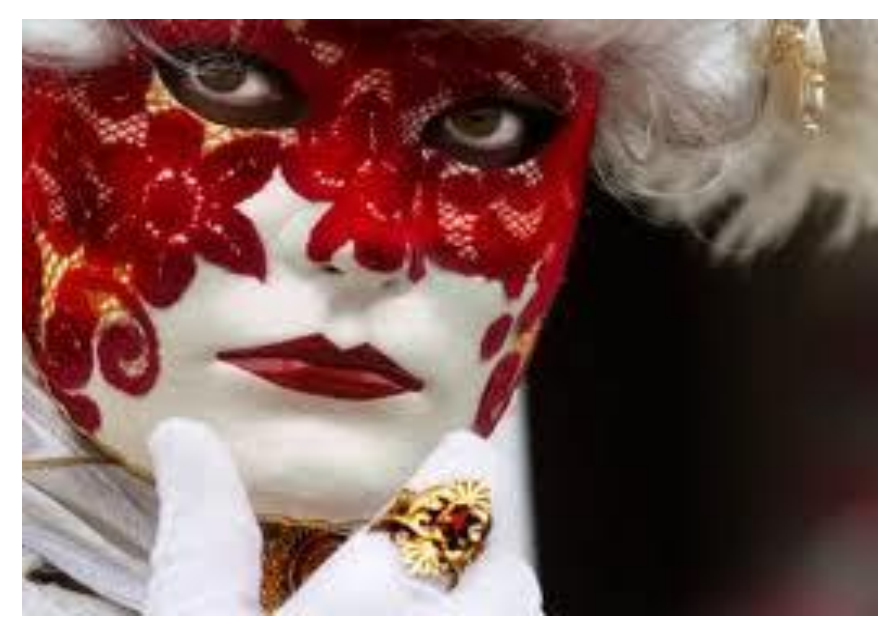

Figura 7: Máscara veneziana.

Fonte: http://artiloka.blogspot.com/2011/02/curiosidades-sobre-as-mascaras-de.html

\subsection{A origem da máscara}

Na pré-história o homem criou a máscara inicialmente pintando o rosto, segundo Ivete Raffa em seu texto "A magia de se trabalhar com máscaras e fantoches", e depois de algum tempo elaborou um objeto para ser usado por diversas vezes, criou as máscaras para tentar incorporar as divindades da natureza como o raio, a chuva e o trovão, bem como os animais poderosos que ele temia, unindo esses elementos em um ritual onde o personagem mascarado invocava o mito, e a história se repetia de maneira que o homem acreditava poder ser o que mais temia, admirava e adorava. A máscara os protegia de doenças, ataque de animais e do inimigo. 


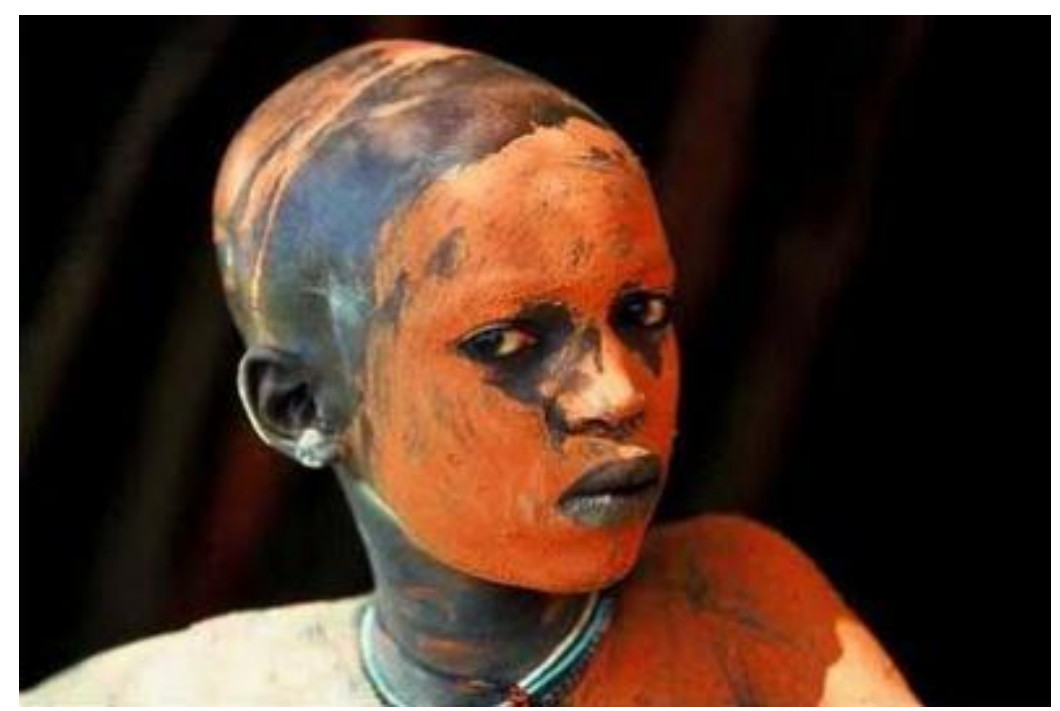

Figura 8: Hans Sylvester. Jovem da tribo Omo, da Etiópia. Fotografia. Fonte: http://blogdangola.blogspot.com/2009/02/as-tribos-omo.html.

Em várias pesquisas e citações encontramos comentários, como Pedro Alcântara em seu texto "A máscara e o Ator", dizendo que o homem pré-histórico via a morte como uma passagem de um estado para outro, e que a máscara era uma forma de fazer o morto retornar por alguns instantes, que estes homens não escreviam, porém desenhavam, caçavam e alguns passaram a dominar o fogo. Questionavam o que acontecia ao seu redor, analisando e percebendo as forças da natureza e vendo que não podiam fazer nada contra um raio ou um relâmpago, acreditando que eram seres muito mais fortes que eles e também imortais, pois já haviam ouvido seus antepassados falarem deles. Então, usavam as máscaras acreditando em seu poder de cura, caça e demais obstáculos que pudessem enfrentar.

\subsection{A máscara na Antiguidade - Egito, Grécia e Roma}

A máscara também se destaca na Antiguidade, período este que vai desde a invenção da escrita (4.000 - 3.500 a.C), até a queda do império romano do Ocidente em 476 d.C. (Equipe Passeiweb). 


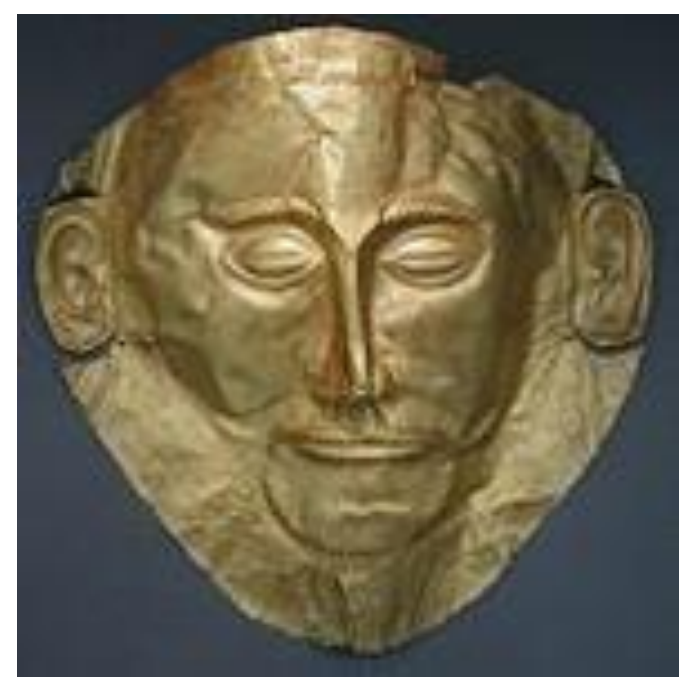

Figura 9: Máscara de Agamenon, máscara funerária em ouro, 1.500 a 1550 a.C. Museu Arqueológico Nacional de Atenas.

Fonte: Coleção Folha "Grandes Museus do Mundo", p. 31.

A máscara como elemento de ritual religioso é marcante no auge da civilização Egípcia, povo que também acreditava na vida após a morte. Em seus rituais funerários, a máscara era usada após a mumificação para identificar o defunto, que deveria ser reconhecido no além. Por isso, por cima das ataduras do corpo do mumificado, colocava-se uma máscara com um retrato idealizado do morto.

Eram em sua maioria, feitas de madeira e pintadas retratando o morto com algumas características, como por exemplo, uma cicatriz ou sinal e, dependendo da classe social a que pertencia o mumificado, a máscara era feita em ouro com pedras preciosas adornando os detalhes, como a dos faraós, feita de ouro e lápis-lazúli. Segundo o mito, a carne dos deuses era de ouro, seu cabelo de lápis-lazúli e os ossos de prata, material muito raro no Egito. Os faraós eram representados como o deus Osíris, soberano dos mortos e, na cabeça levava o Nemes, adorno listrado enfeitado na parte da frente com a serpente protetora dos faraós (Marucci, 2.001). 


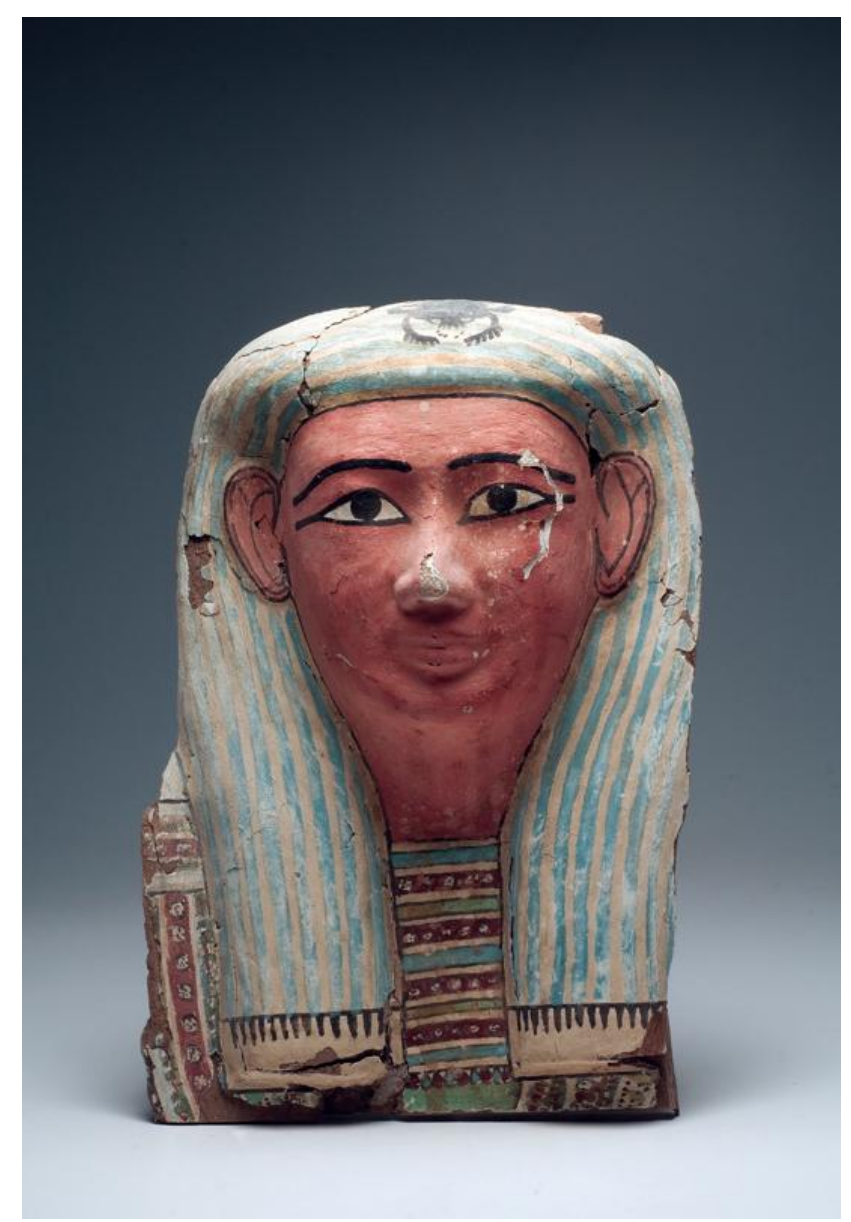

Figura 10: Máscara mortuária egípcia em madeira, 700 a 30 a.C. $51 \mathrm{~cm}$ de altura. S.A. Gallery, Vilamoura.

Fonte: $h$ ttp://www.sagallery.com.

Um exemplo bastante conhecido de máscara Egípcia é a Máscara Mortuária de Tutancâmon, faraó que assumiu o trono do Egito aos nove anos e morreu aos dezoito, em 1337 a.C. Sua tumba foi encontrada por Howard Carter em 26 de novembro de 1922 D.C.

Dentre o grande tesouro encontrado na tumba, está a Máscara Mortuária que cobria a múmia de Tutancâmon dentro do sarcófago, uma peça de ouro com incrustações de lápis-lazúli, colocada diretamente sobre a múmia, cobrindo a cabeça e parte dos ombros. Podemos ver o enfeite de cabeça Nemes, outro enfeite listrado e a barba postiça trançada. O enfeite de cabeça com as deusas Nekhebet e Uadjit, a primeira representada como abutre e a segunda como cobra, protegiam o faraó (JAMES, T. G. HENRY. Tutancâmon. Biblioteca Egito. Editora Folio, 2.005). 


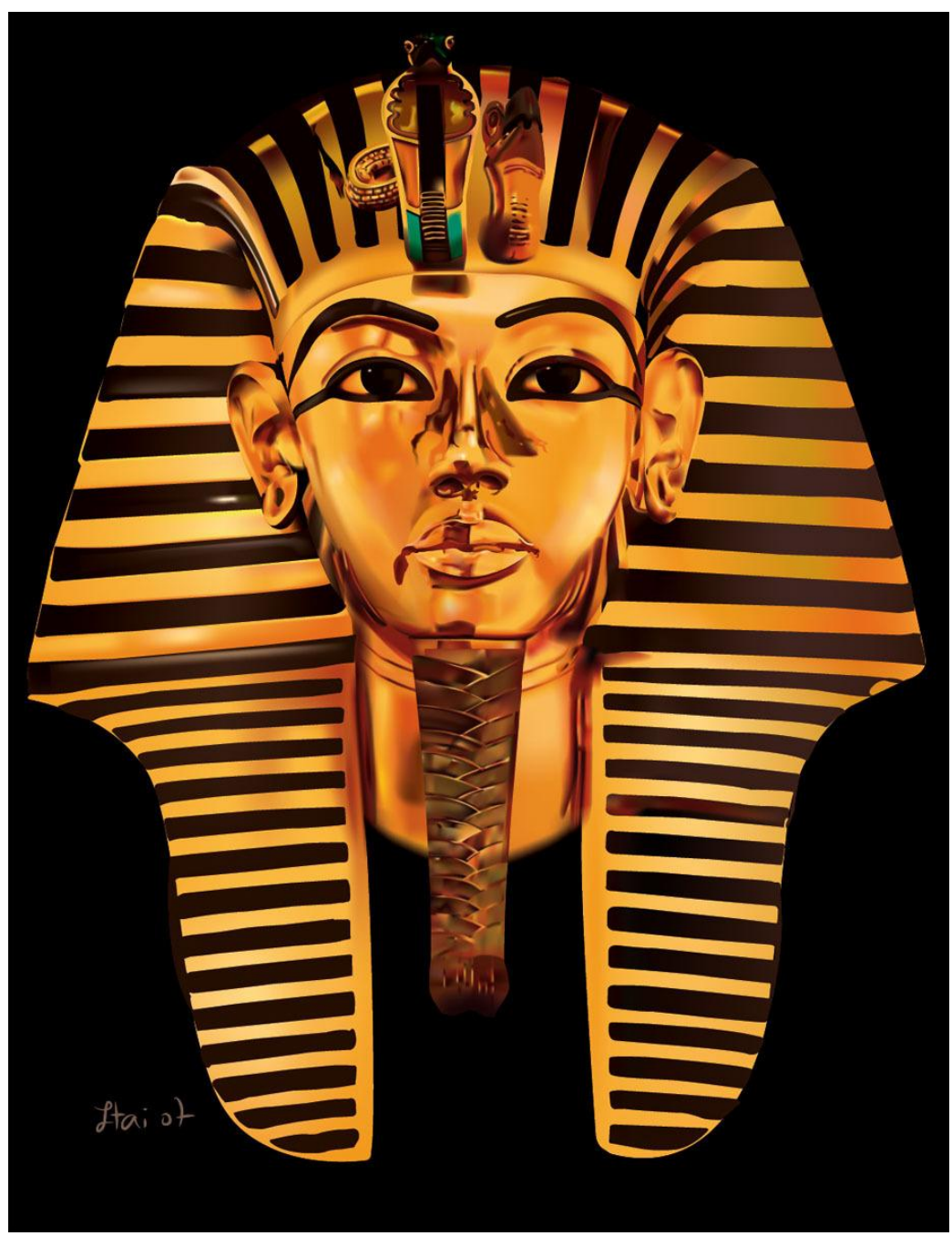

Figura 11: Máscara mortuária de Tutancâmon. Mascara de ouro incrustado de pedras semipreciosas. Vale dos Reis.

Fonte: http://anapauarte.blogspot.com/2011/08/el-arte-en-egipto.htmI

Já a civilização Grega teve seu apogeu no século V a.C., mesmo período em que o teatro havia se desenvolvido a partir de rituais das festas em homenagem a Dionisio, havendo apresentações das tragédias gregas. As máscaras gregas eram inicialmente confeccionadas com folhas, madeira, argila e couro (DURANDO, FURIO. A Grécia Antiga. Grandes Civilizações do Passado. Editora Folio, 2.005). 


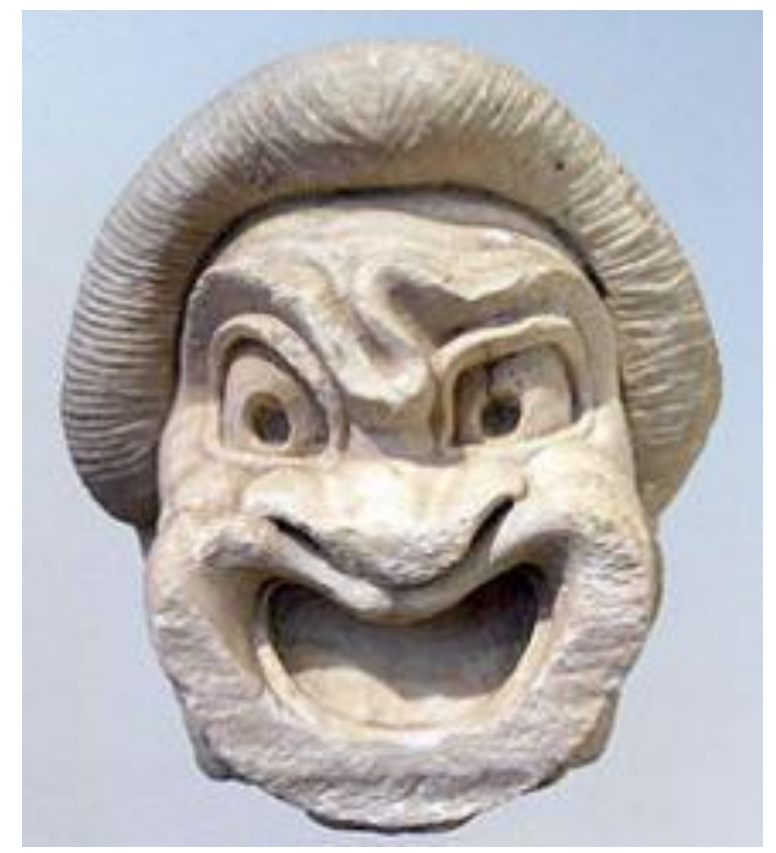

Figura 12: Máscara teatral do tipo Primeiro Escravo, personagem típico da Comédia Nova. Mármore, século Il a.C. Museu Arqueológico Nacional de Atenas. Fonte: Coleção Folha "Grandes Museus do Mundo", p. 16

Os romanos se apropriaram de variados elementos da cultura grega inclusive o uso de máscaras em seu teatro, denominados de personas e larvas que indicava também às características expressivas e físicas dos personagens, fora do teatro a máscara se fazia apenas como uma pintura no rosto (LIBERATI, ANNA MARIA; BOURBON, FABIO. A Roma Antiga. Grandes Civilizações do Passado. Editora Folio, 2.005).

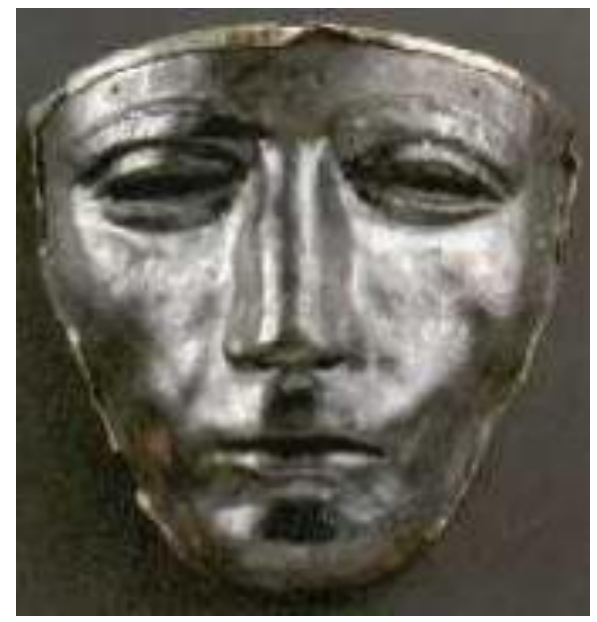

Figura 13: Máscara romana de Kalkriese.

Fonte: http://librodenotas.com/losanalesperdidos/10136/devue/veme-mis-legiones. 
$\mathrm{Na}$ antiguidade, além de serem usadas como diversão, as máscaras chamadas de "públicas", faziam parte de rituais mágicos para esconjurar os maus espíritos, com a função de mostrar o semblante desejado ou de prevenção de algumas enfermidades, podendo ainda limpar ou purificar algum enfermo. Fazia com que ao mascarado coubesse a missão de expulsar da natureza e das populações os maus espíritos e o mal em geral.

Também era um elo entre o mundo dos vivos e dos mortos. Usada em rituais propiciando um regresso das almas dos defuntos para gratificarem ou castigarem os vivos, ocasião em que o mascarado era o elemento de legação entre uns e outros, sentido de harmonia e do entendimento pela realização das práticas a que não são alheios o exorcismo e a magia em uma relação entre vivos e mortos. O mascarado se mantém como elemento superior e fantástico, possuidor de dons especiais, e sua presença se torna indispensável, visitando casas, recebendo ofertas e avaliando atitudes com censura ou julgamento público das pessoas (COSTA, 2008).

Na mitologia grega, Baco e Dionísio eram indigitados como deuses da mascara e, no templo de Artémis, deusa grega, as sacerdotisas se apresentavam mascaradas para os rituais de iniciação. 


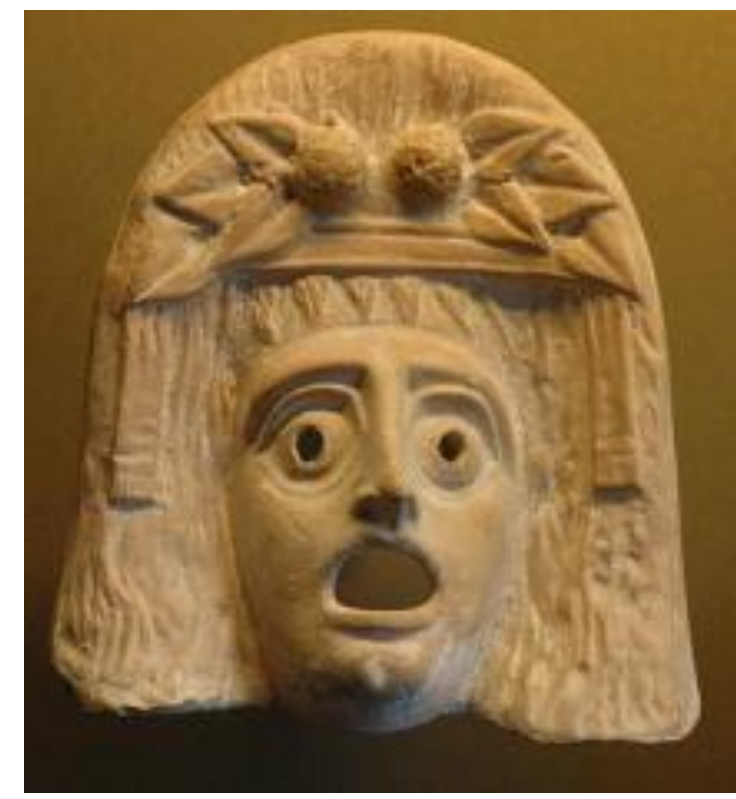

Figura 14: Máscara de Dionísio, Myrina, século II a.C.

Fonte: http://dimensaoestetica.blogspot.com/2010/07/do-tragico-ao-abjeto.html.

\subsection{A máscara como elemento ritualístico}

A máscara é um objeto que cobre todo o rosto e proporciona ao usuário uma identidade diferente da sua, um retrato ou apenas uma tela protetora. Já com sentido ritualístico, é criada para ser habitada por espíritos (professor Lindomar, 2.007, infoescola). É visível a mudança de identidade do usuário da máscara, que acredita entrar em contato com os espíritos ou até mesmo incorporá-los. Quanto ao portador da máscara, podemos dizer que este veste uma máscara acreditando estar mesmo em contato direto com o espírito, podendo ser afetado por ele, sendo preciso assim, tomar alguns cuidados para se proteger e mostrar seu respeito, pois sem dança, gestos e emissão de sons, a máscara não terá vida.

Usando a máscara, a pessoa deixa sua identidade assumindo a do personagem, podendo sofrer alterações psíquicas que aumentam à medida que o transe o incorpora. Perdendo sua identidade, perde também sua vontade, pois está em comunicação com o outro e desamparado. Porém, se sente poderoso e forte, acreditando por vezes, possuir poder sobre as forças do universo. O papel da 
máscara em um ritual é de fundamental importância, pois remete o usuário ao passado fazendo os espectadores interagirem na cerimônia, até mesmo fazendo-os entrar em transe também. As divindades incorporadas podem ser tanto alegres, divertidas e companheiras, como más, guerreiras e demoníacas (Daniele Gianini, Lugares do Mundo).

Referindo-se às suas funções nos rituais relatados acima, as máscaras são usadas para manter o equilíbrio religioso e cultural de um povo, sendo usadas roupas especiais com cerimônias noturnas e acompanham geralmente oferendas. As máscaras antropomórficas são usadas para associar a morte com a partida dos espíritos. Essas possuem os traços do falecido, protegem o morto dos maus espíritos e homenageia-o. Dependendo da personalidade do morto, a máscara era adornada com pedras preciosas, feitas com metais ou casca de árvore e pano (JAMES, T. G. Henry. Tutancâmon. São Paulo: Ed. Folio, 2005).

Como uso terapêutico, a máscara é usada em algumas culturas para prevenir e curar algumas doenças, o mascarado pode guiar o demônio para fora da tribo ou do povo, são máscaras em formatos estranhos que "assustam todo o mal", como comenta Ferras Lesly em sua monografia em 2.009. Dentro de uma tribo ou sociedade, a máscara adquire a forma apropriada para os determinados fins tendo, por exemplo a máscara para o ritual da fertilidade ou da iniciação sexual, ou casamento, cada uma com suas características próprias. 


\section{A MÁSCARA NO BRASIL}

No Brasil, as máscaras ocidentais surgiram no carnaval no século XVII, mas em janeiro de 1840 , os donos do Hotel Itália no Rio de Janeiro, motivados pelas noticias vindas da Europa e sobre o sucesso dos bailes de máscaras da localidade, promoveram o primeiro baile de máscaras (Cardoso, Monique. 2004). Ganhando mais adeptos em 1834, as máscaras vinham da França e eram confeccionadas em uma camada de cera muito fina, ou então papelão, que reproduziam caretas ou ainda cara de animais. Elas passaram a fazer parte do carnaval brasileiro, que surgiu de uma mistura de culturas européias e se adaptaram ao nosso clima e ao nosso povo sempre festeiro. Os bailes que aconteciam nos clubes do Brasil na época do carnaval refletiam a moda francesa, principalmente os bailes de máscaras que eram realizados a séculos.

Sendo para fins religiosos, artísticos, para disfarce, fetiche, na ciência, no esporte ou em festas, as máscaras possuem muitas possibilidades de uso variando e adaptando-se à época e cultura em que está inserida. Quando se trata de ficção, a máscara é um elemento certo para que o herói mantenha sua identidade preservada ao mesmo tempo em que lhe permite incorporar e fazer parte de um novo universo (professor Lindomar, Infoescola).

\subsection{Máscaras indígenas}

Desde que surgiu na história da humanidade, a máscara exerceu fascínio sobre alguns seres humanos que a usam para diferentes finalidades. No Brasil 
podemos encontrar algumas tribos que ainda matem em sua cultura o uso das máscaras em rituais, acompanhadas com bailados e gingas, como os Caraíbas Araucos e os Uananas da família Tucuno no Amazonas. As duas tribos realizavam rituais de sepultamentos aos mortos da tribo e eram bastante parecidos entre si: suas máscaras eram feitas de casca de algumas árvores (Equipe de edição da Enciclopédia Povos Indígenas no Brasil).

Já na tribo Karajá, propriamente na dança do Aruanã que representam os heróis e mantêm a ordem no mundo, as máscaras são feitas de cabaças, palha de buriti e cascas de troncos das árvores.

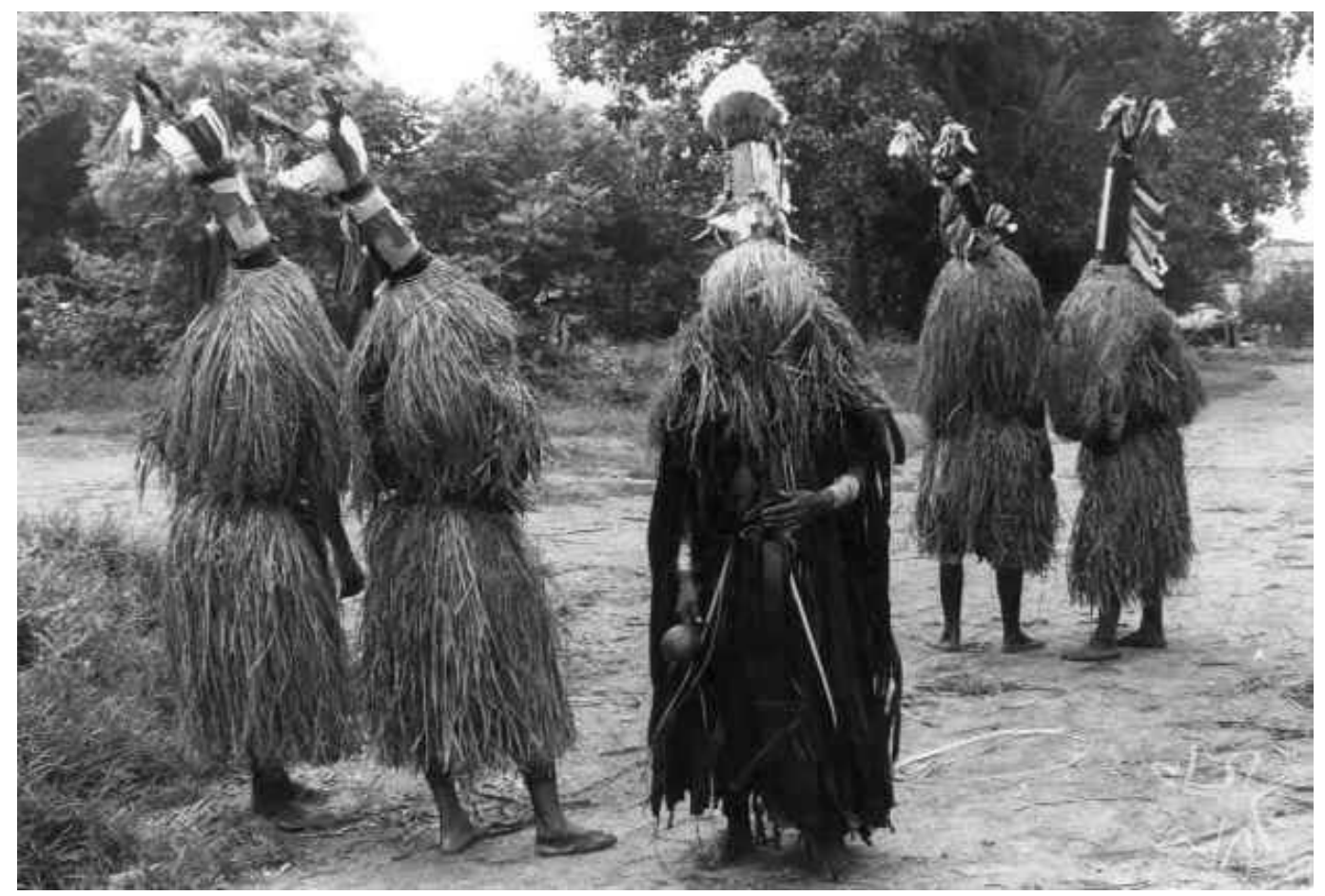

Figura 15: Walter Sanchez. Aldeia Macaúba, Aruanã, llha da Banana, 1986. Fotografia. Fonte: http://pib.socioambiental.org/pt/povo/karaja/374.

Os índios Waujá, da aldeia Piyulaga, repetem o ritual de convocação dos espíritos de doença e cura, festa esta que dura cerca de duas semanas. Além de ser uma forma de exibir seu enfeites de pinturas corporais, penas e pele de jaguar, ainda representam as divindades com grandes máscaras redondas feitas com palha, dançam e cantam enquanto tocam flautas e maracás (Eugênia Fernandes, 2005). 


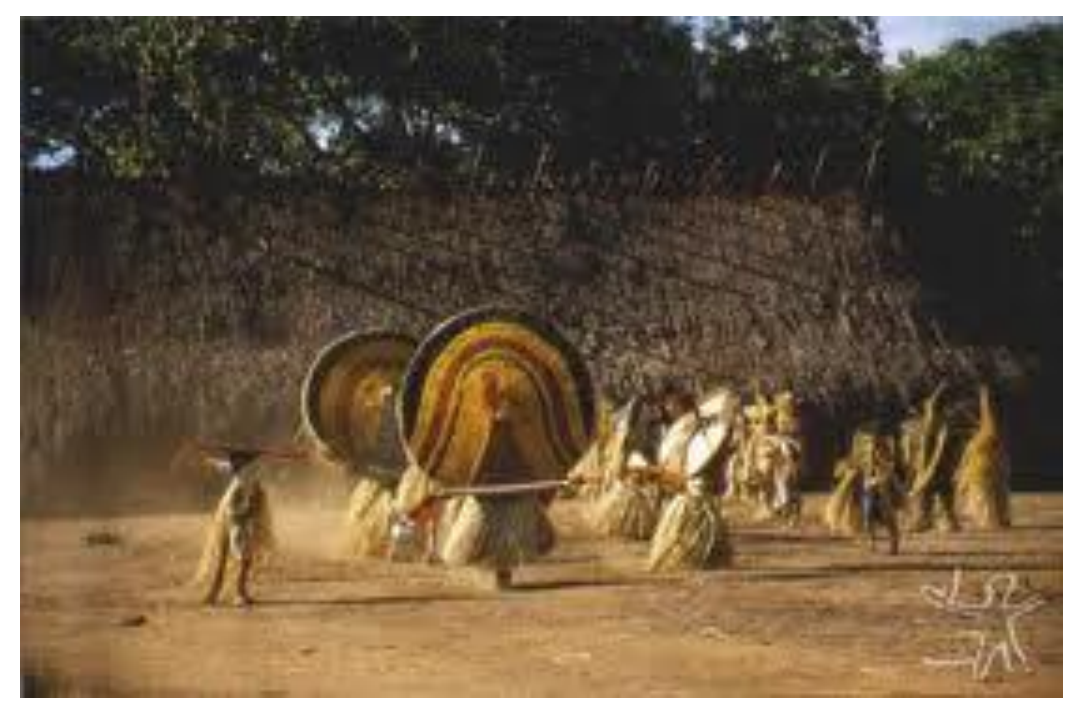

Figura 16: Aristóteles B. Neto. Tribo Waujá, Aldeia Piyulaga, 2002. Fotografia. Fonte: http://pib.socioambiental.org/pt/povo/wauja/print.

Na tribo dos índios Wayana-Apalay, que vivem no norte do Pará na fronteira com Suriname e Guiana Francesa, usavam a máscara chamada "Tamokos", que é um personagem de uma lenda da tribo. Esses personagens seriam divindades que vivem na floresta e são homenageados nos rituais que os índios realizam antes da construção de uma nova oca: a Festa da Cumeeira. Os índios se vestem de Tomokos e cantam e dançam, e suas máscaras são feitas da fibra do arumã e cobertas com cera de abelha, sendo depois pintadas com barro branco e tinta de pedra vermelha. A máscara ainda tem um corpo feito com as fibras das cascas da árvore Atê, podendo ainda ter fios de algodão (landé Arte com Historia, 2009). 


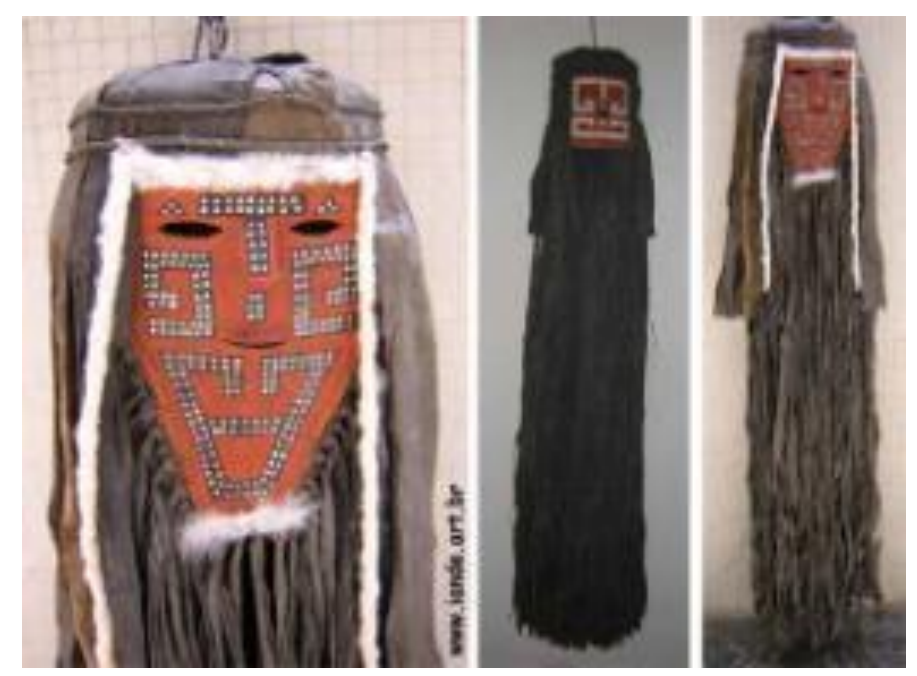

Figura 17: Máscaras do sobrenatural "Tomokó", índios Wayana-Apalay, Pará. Fonte: http://www.iande.art.br/mascara/diversos/wayanatamokoh0403.htm

A máscara Kokrit, dos índios Krahó e Kanela, habitantes do norte do estado de Tocantins, têm idioma e costume bastante parecidos, pois realizam a festa do espírito Kokrit que é uma entidade descrita como um artrópode (animal invertebrado) sobrenatural que vive nas águas do rio Tocantins. O Kokrit é representado por uma máscara que cobre todo o corpo e é formada por duas esteiras feitas de palha de buriti trançadas e franjas longas que vão até o chão e no alto, dois chifres de madeira. As pinturas das máscaras se diferenciam para representar os personagens da sociedade Kokrit (landé Arte com Historia, 2009).

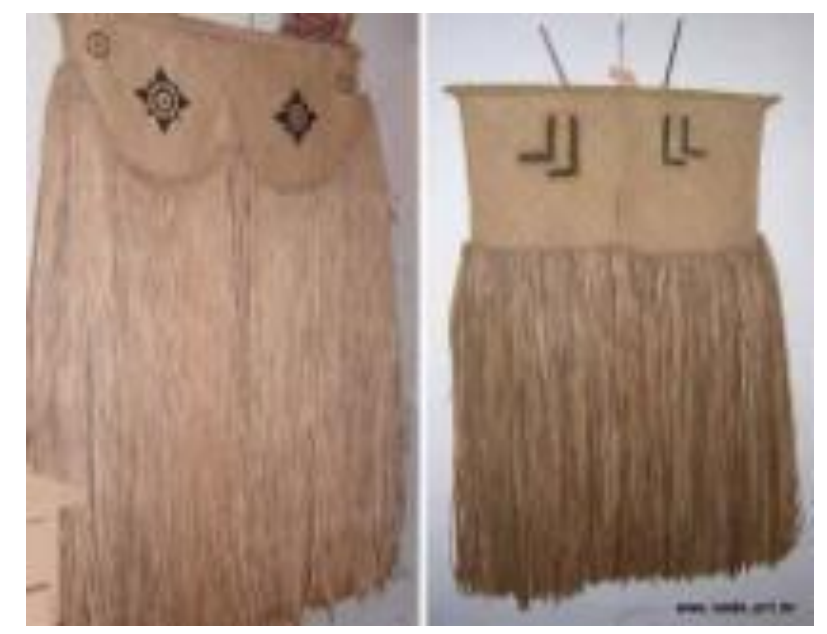

Figura 18: Máscaras do sobrenatural Kokrit dos índios Kanela (à direita) e dos índios Kahó (à esquerda). Fonte: http://www.iande.art.br/boletim030.htm. 


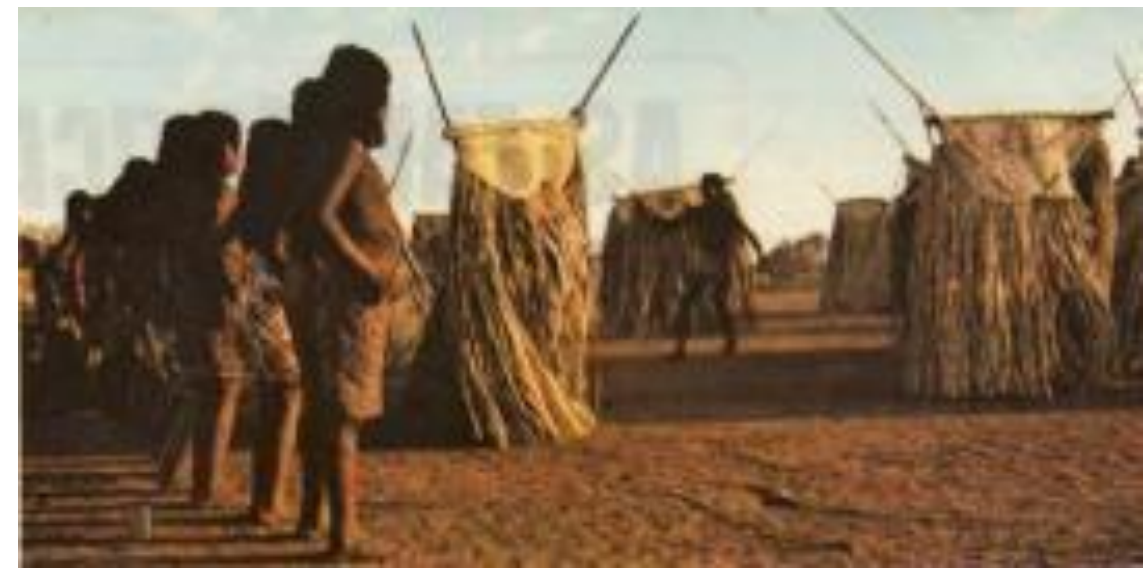

Figura 19: Festa dos Kokrit, índios Kanela.

Fonte: http://www.iande.art.br/boletim030.htm.

Verificamos assim, que cada tribo possui suas características particulares e que a máscara surge como importante elemento presente em diferentes rituais em cada uma destas culturas. 


\section{A MÁSCARA NA CONTEMPORANEIDADE}

O uso da máscara na atualidade é um tanto amplo, sendo utilizada para os mais diversos fins, diferente de sua origem que era em rituais religiosos. Hoje a máscara é também usada como elemento de arte, compondo um personagem teatral ou um figurino para festa, como forma de evitar propagação de doenças em epidemias ou cirurgias, como também para esconder a identidade de ladrões e terroristas. Vemos que as máscaras se tornaram também um elemento que pose ser usado tanto para defesa como para o ataque.

Ainda encontramos a máscara sendo usadas na sociedade de diversas nações, estando ligada a cultura de um povo, como por exemplo, festas religiosas ou mesmo pagãs, como bailes e desfiles de carnaval. No México são usadas máscaras em formato de caveira para cultuar os mortos em festividade que acontece anualmente e, na noite de 1ำ de novembro, são preparadas as tumbas nos cemitérios com muita comida, música e velas, onde os vivos esperam a vinda dos mortos para passarem um dia juntos, tornando-se uma grande celebração da vida, para eles os mortos continuam vivos enquanto nos lembramos deles (Silva, Simone Andrea Carvalho da. Novembro de 2.007). 


\section{CONSIDERAÇÕES FINAIS}

Durante a aplicação de um trabalho sobre máscaras em sala de aula, alguns alunos se esquivaram no início, alegando não gostarem de elementos antigos ou momentos de um passado que não acompanharam, mas, ao desenvolverem as atividades, mudaram de opinião e se interessaram em realizar as atividades propostas, com muita dedicação e entusiasmo, pois passaram a experimentar técnicas e perceber que existem maneiras diferentes que podem usar para expressar suas idéias, emoções e conhecimento, desenvolvendo habilidades que nem mesmo eles sabiam possuir.

A ornamentação das máscaras levou os alunos a expressarem suas idéias e a buscarem novas maneiras de realizá-las, com a busca de novos materiais para a decoração, desenvolveram técnicas de como fixar os elementos no suporte e descobrir novos materiais para fazê-lo em tentativas diversas com elementos que nunca haviam tentado antes, percebendo que o passado pode ser moderno. Usaram o elemento máscara, que é um objeto de origem pré-histórica que veio se desenvolvendo no decorrer do tempo, acompanhando a evolução do homem, modificando seu material e assumindo características distintas, suprimindo as necessidades específicas exigidas de cada cultura e momento histórico, até os dias de hoje em que materiais como: sementes, pequenas peças de computador, parafusos e frascos plásticos coloridos que seriam jogados na natureza sem cuidado algum, podem ser usados para o fazer artístico decorando suas máscaras.

A máscara foi usada neste projeto como mais um elemento pedagógico onde $\mathrm{o}$ aluno pôde expressar seu conhecimento adquirido durante o processo de pesquisa e elaboração das peças ou simplesmente expressar suas ideias e sentimentos. Este foi um trabalho que uniu todos os alunos em um único objetivo: expressar-se através da máscara, podendo não somente criar ou recriar um elemento do passado como criar novas máscaras com elementos diversos. $\mathrm{Na}$ aplicação do projeto nenhum aluno da turma se mostrou indiferente, no inicio alguns se mostraram arredios, mas no decorrer das aulas todos se envolveram produzindo seus trabalhos, percebendo que são capazes de se expressarem através da arte 


\section{REFERÊNCIAS}

ALCÂNTARA, Pedro. A máscara e o ator. [online] Disponível na internet via WWW. URL: <http:/www.ybytucatu.com.br> Acesso em: 20/09/2011.

CARDOSO, Monique. Os primeiros Bailes de Carnaval no Brasil. In: Carnaval do Brasil. [online] Disponível na internet via WWW. URL: <http://www.carnavaldobrasil.com.br> Acesso em: 12/09/2011.

COSTA, Soledad Martinho. Carnaval - a máscara. [online] Disponível na internet via WWW. URL: $<$ http://sarrabal.blogs.sapo.pt> Acesso em: 15/10/2011.

DURANDO, Furio. A Grécia Antiga. São Paulo: Ed. Folio, 2005 (Coleção Grandes Civilizações do Passado).

EINAUDE, Silvia. Museu Egípcio do Cairo. São Paulo: Ed. Folha de São Paulo, 2009. (Coleção Folha Grandes Museus do Mundo, Volume 4).

Equipe de edição da Enciclopédia Povos Indígenas no Brasil. [online] Disponível na internet via WWW. URL: <http://www.pib@socioambiental.org> Acesso em : 14/10/2011. Equipe Passeiweb. Idade Antiga. Disponível na internet via WWW. URL: In <http://www.passeiweb.com> Acesso em: 13/10/2011FERNANDES, Eugênia. _Dança das máscaras indígenas vai para o museu. [online] Disponível na internet via WWW. URL:<htt://www.rfi.fr> Acesso em: 14/10/2011

GIANNINI, Danielle. Arte e Artesanato - Máscaras. In: Lugares do Mundo. [online] Disponível na inernet via WWW. URL:<http://www.lugaresdomundo.com/mascaras_0803.htm>. Acesso em: 12/09/2011.

CASA DE CULTURAS INDÍGENAS, landé. [online] Disponível na internet via WWW. URL:< http://www.iande.art.br/arteindigena.htm>. Acesso em 14/10/2011

JAMES, T. G. Henry. Tutancâmon. São Paulo: Ed. Folio, 2005. (Coleção Biblioteca Egito).

LESLY, Ferras. Máscaras. In: Monografias. [online]. Disponível na internet via WWW. URL: <http://www.monografias.com/trabajos7/masca/masca.shtml>. Acesso em: 10/09/2011.

LIBERATI, Anna Maria; BOURBON, Fabio. A Roma Antiga. São Paulo: Ed. Folio, 2005. (Coleção Grandes Civilizações do Passado).

MARUCCI, Liege; SOUZA, Maria de. O Fascinante Mundo do Antigo Egito. São Paulo: Ed. Planeta, 2001 (Coleção Egitomania, Volume 1)

MOZZATI, Luca. Museu Arqueológico Nacional de Atenas. São Paulo: Ed. Folha de São Paulo, 2009 (Coleção Folha Grandes Museus do Mundo, Volume 9).

SANTANA, Ana Lucia. História das Máscaras. In: Info Escola. [online] Disponível na internet via WWW. URL: <http://www.infoescola.com/artes/historia-das-mascaras/> Acesso em: 11/10/2011.

SILVA, Simone Andréa Carvalho da. Festa dos mortos para celebrar a vida. In: Revista Planeta. Nov. 2005. [online]. Disponível na internet via WWW. URL:

<http://www.terra.com.br/revistaplaneta/mat_398.htm> Acesso em: 10/11/2011. 
